Journal homepage: www.aesacademy.org

\title{
Impact of jute retting on physicochemical profile of Chhariganga oxbow lake in Nadia district, West Bengal, India
}

\author{
Dipankar Ghosh ${ }^{1}$ and Jayanta Kumar Biswas ${ }^{1,2^{*}}$
}

${ }^{1}$ Department of Ecological Studies, University of Kalyani, Kalyani-741235, (West Bengal), INDIA

${ }^{2}$ International Centre for Ecological Engineering, Department of Ecological Studies, University of Kalyani, Kalyani-741235, (West Bengal), INDIA

*Corresponding author's E-mail: biswajoy2000@yahoo.com iD

\section{ARTICLE HISTORY}

Received: 16 January 2018

Revised received: 31 January 2018

Accepted: 19 February 2018

\section{Keywords}

Gross primary productivity (GPP) Jute retting

Net primary productivity (NPP)

Oxbow lake

Physico-chemical properties

Water quality

\begin{abstract}
The present study was carried out to assess the ecosystem of the Chhariganga, an oxbow lake in eastern India to assess the pollution due to jute retting and trophic status on broader aspects for its sustainable management. The physicochemical analyses of the studied oxbow lake showed the range with annual mean values of surface water temperature in ${ }^{\circ} \mathrm{C}(11-37,27.64 \pm 6.56)$, water transparency in $\mathrm{cm}(16-106,45.82 \pm 23.39)$, water $\mathrm{pH}(7.4-8.8,8.17 \pm 0.34)$, DO (2.60-7.85, 4.65 $\pm 1.52 \mathrm{ppm}), \mathrm{BOD}(1.10-6.40,2.98 \pm 1.59 \mathrm{ppm}), \mathrm{COD}(70-90,79 \pm 7.38 \mathrm{ppm}), \mathrm{NH}_{4}-\mathrm{N}(0.026-0.093$, $0.05 \pm 0.02 \mathrm{ppm}), \mathrm{NO}_{2}-\mathrm{N}(0.008-0.08,0.03 \pm 0.02 \mathrm{ppm}), \mathrm{NO}_{3}-\mathrm{N}(0-2.459,0.81 \pm 0.69 \mathrm{ppm}), \mathrm{OP}(0.067-$ $0.62,0.26 \pm 0.18 \mathrm{ppm})$, total alkalinity $(82-165,120 \pm 24.03 \mathrm{ppm})$, total hardness $(70-138$, 102.62 $\pm 19.60 \mathrm{ppm})$, GPP (0.30-1.80, $1.25 \pm 0.47 \mathrm{mgC} / \mathrm{l} /$ day $)$, NPP $(0.15-1.38,0.95 \pm 0.40 \mathrm{mgC} / \mathrm{l} / \mathrm{day})$; sediment $\mathrm{pH}(6.8-7.9,7.53 \pm 0.34)$ and sediment organic carbon in $\%(1.87-2.89,2.17 \pm 0.28)$. The highest mean values of BOD (4.59ppm), COD $(86.67 \mathrm{ppm})$, OP $(0.50 \mathrm{ppm})$, sediment organic carbon (2.29\%) were observed during monsoon whereas the lowest values of oxbow lake water's transparency $(27.00 \mathrm{~cm}), \mathrm{pH}(7.84), \mathrm{DO}(3.63 \mathrm{ppm})$ and $\mathrm{NO}_{2}-\mathrm{N}(0.01 \mathrm{ppm})$ contents were found during monsoon when jute retting process intensified in the oxbow lake. Compared to their values in pre-monsoon, mean values in monsoon showed an increase in BOD (182.57\%) and OP content (167.64\%) unlike reduction in water transparency (62.54\%), GPP and NPP (both reduced by about 50\%); The highest concentration of $\mathrm{NH}_{4}-\mathrm{N}$ and $\mathrm{NO}_{3}-\mathrm{N}$ were noticed during post-monsoon and OP during monsoon. The water transparency mean values showed sharp fall during monsoon from pre-monsoon. Physico-chemical analyses revealed that almost all parameters in oxbow lake did not show significant changes throughout the year unlike water transparency, $\mathrm{BOD}, \mathrm{NO}_{2}$ and especially OP content of water which otherwise showed significant changes throughout the year. The present semi-closed oxbow lake water was of poor to moderate quality and it was classified as oligo-mesotrophic in nutrient status with high to moderate organic pollution due to jute retting process which needs to be controlled and regulated for sustainable aquaculture in oxbow lake ecosystem.
\end{abstract}

(C)2018 Agriculture and Environmental Science Academy

Citation of this article: Ghosh, D. and Biswas, J.K. (2018). Impact of jute retting on physicochemical profile of Chhariganga oxbow lake in Nadia district, West Bengal, India. Archives of Agriculture and Environmental Science, 3(1): 36-44 DOI: 10.26832/24566632.2018.030104

\section{INTRODUCTION}

Oxbow lakes being natural depressions and kidneys of the landscape have great ecological and socio-economical importance (Ghosh and Biswas, 2015a, d). They are subject to various human activities, pollution, eutrophication, use of agricultural pesticides in catchment areas, jute retting. Excavation and large scale pit extraction disfigure oxbow lakes landscapes and limits their values for other (Ghosh and Biswas, 2015d). The effects of siltation, habitat destruction, and macrophyte infestation, isola- 
tion from river flow, flood water, inadequate rainfall and nutrient influx in changed climate have degraded oxbow lake environments as a whole. Habitat loss or modification is often associated with habitat fragmentation. Jute retting during monsoon is a common anthropological activity in the rural Bengal (Ghosh and Biswas, 2015e). Population pressure, urbanization, industrialization and increased agricultural activity including jute retting have significantly contributed to the pollution and toxicity of aquatic ecosystems including oxbow lakes. Pollutants bring about a change not only in the physical and chemical quality of water but also modify the biotic components, resulting in the elimination of some potentially valuable species. The impact of urbanization the urbanization of surrounding areas leads to the discharge of domestic sewage and industrial effluents into lake (Chandrasekhar et al., 2003). Varied studies have been conducted on oxbow lake ecosystems across the world in general (Banerjea, 1967; Zutshi et al., 1972, 1980; Vass and Zutshi, 1979; Trisal, 1985; Patil and Panda, 1986; Joo and David, 1995; Nandan, 1997; Sugunan et al., 2000; Obire et al., 2003; Aswathi and Tiwari, 2004; Chindah et al. 2005; Hart and Zabbey, 2005; Sikoki and Zabbey, 2006; Koliyar and Rokhare, 2008; Joadder, 2009; Feresin et al., 2010; Das et al., 2009, 2011, 2011a) and in Nadia district in particular (Dasgupta et al., 2006; Biswasroy et al., 2011; Bala and Mukherjee, 2011; Ziauddin et al., 2013). Despite studied effect of jute retting on the water of an oxbow lake (Dasgupta et al., 2006) and assessed impact of jute retting on native fish diversity and aquatic health of roadside transitory water bodies (Ghosh and Biswas, 2015c) considering limited parameters, the present study was specifically conducted to revisit the impact of jute retting on physico-chemical condition of a randomly chosen semi-closed oxbow lake ecosystem (Ghosh and Biswas, 2017b; 2017d) in the northern side of the Nadia district, West Bengal through the analyses of as much as 16 physico-chemical parameters during April 2013-March, 2014 to assess the pollution due to jute retting and trophic status on broader aspects for its sustainable management.

\section{MATERIALS AND METHODS}

\section{Study area}

The Chhariganga oxbow lake is located in Nakashipara development block of Nadia district, West Bengal, India $\left(23.5779214^{\circ} \mathrm{N}, 88.3471226^{\circ} \mathrm{E}\right)$. This lake is situated at about $90 \mathrm{Km}$ away from Kalyani university campus, Nadia and nearly $40 \mathrm{~km}$ north of the tropic of cancer line. The Chhariganga oxbow lake was formed as an abandoned meander of the river Ganga and is freshwater, semi-closed oxbow lake that receives water from the Ganga River, during monsoon, through a narrow channel at the north-east corner of a loop of the river. The Chhariganga oxbow lake also stores rain water. This oxbow lake is spread over an area of 58.28 ha with an annual average depth of $2.6 \mathrm{~m}$. The catchment area of the oxbow lake is nearly 600 ha. The oxbow lake was selected at random among a total of 122 similar oxbow lakes in Nadia District, West Bengal (Ghosh and Biswas, 2017b; 2017d). There are three distinct annual seasons in this region: pre-monsoon or dry season, from March to June; monsoon, or rainy season, from July to October (within this period jute retting takes place, generally from August to September); and post-monsoon or winter season, from November to February. There have been occasional inundations of the surrounding banks during monsoon. The Chhariganga Lake is subjected to all forms of human activities including jute retting during monsoon, agriculture and fishing. It is the only source of irrigation water to the immediate agriculture communities. The Chhariganga oxbow lake has taken different names in four different development block locations like "Errerdanga Chhariganga", "New Chhariganga" along its largest (about 88.63 ha) segment in Kaliganj,"Bhagirathi Chhariganga" in Nabadwip, "Chhariganga" in Nakashipara and "Chhariganga Oxbow lake" in Santipur covering a total recorded area of 207.20 ha. This lake is important because it accounts for around $8.69 \%$ of the total oxbow lake Government area of water bodies and is probably the sole example of a semi-closed type oxbow lake in the district. This oxbow lake has an estimated average effective water spread area (EWSA) of 33.33 ha, that accounts for about $57 \%$ of a recorded water body area (RAW) of 58.28 ha, as registered by the land and land revenue department of West Bengal from April 2013 to March 2014. In this 12-month period, flood water entered the lake enhancing its EWSA and its annual average water depth of $2.55 \mathrm{~m}$. Thus, the volume of the EWSA (in millions of tons) was estimated to be $0.42,1.50,0.77,0.85$, and 0.90 for pre-monsoon, monsoon, post-monsoon, annual average, and annual total, respectively. The Chhariganga oxbow lake has on average 600 jute retting units of mean size $30 \mathrm{~m} 2$, with each unit covering about $3.6 \%$ of the EWSA (3.09\% of RAW) and consuming a water volume of more than $5 \%$ of the total EWSA annual average during monsoon (Table 1). Ultimately, the present study focused on $28.13 \%$ of the whole Chhariganga's recorded area $(2.44 \%$ and 11 th largest of the total oxbow lakes as public water bodies in the district) which is in Nakashipara Block.

\section{Collection of water and sediment samples}

For well mixed waters (i.e. water free from any aquatic weed and not isolated by any fishing enclosure), a sample was taken within $1 \mathrm{~m}$ below the surface and away from the edge. To collect a sample of the surface layer, a $500 \mathrm{ml}$ polypropylene bottle was held horizontally and half submerged. All samples for chemical analysis were taken between 8 and 9 am of the sampling day. Sediment was collected from different locations and depths of the Chhariganga oxbow lake ecosystem and mixed thoroughly. All collected samples were pooled into one to make a composite sample for chemical analyses (Ghosh and Biswas, 2017d).

\section{Analyses of physico-chemical parameters}

Water physicochemical parameter analyses were carried out during the pre-monsoon, monsoon and post-monsoon seasons (from April 2013 to March 2014). Analyzed parameters for all water samples included (Ghosh and Biswas, 2017d): (i) temperature, recorded on the spot with a WTW Multi-parameter portable meter MultiLine"R (F/SET-3, Weilheim, Germany); (ii) trans- 
parency, assessed with a metallic Secchi disc of $20 \mathrm{~cm}$ in diameter with four quadrants of alternate black and white colours on the upper surface. The disc was ballasted on the ower surface and suspended with a graduated cord at its center. (iii) Water $\mathrm{pH}$, measured using a WTW Multi-parameter portable meter MultiLine"R (F/SET-3, Weilheim, Germany). For pH, the averaging across samples procedure described by Boyd (1992) was used, $\mathrm{pH}$ readings were converted to hydrogen ion concentrations and these were then averaged. (iv) Dissolved oxygen in the lake water was measured with a specific probe of a WTW Multi-parameter portable meter MultiLine"R (F/SET-3, Weilheim, Germany). (v) Biochemical oxygen demand (BOD) was obtained following Selvaraj (2005) and Ghosh \& Biswas (2015c). This is an in situ method that consisted of filling an 250 $\mathrm{ml}$, airtight bottle and incubating it at in situ temperature for 1 day. Dissolved oxygen (DO) was measured, by the Winkler method, before and after incubation, and the BOD was computed from the difference between initial and final DO. (vi) Chemical oxygen demand (COD) was determined using a digestion mixture of $0.25 \mathrm{~N}$ potassium dichromate and concentrated $\mathrm{H}_{2} \mathrm{SO}_{4}$ (5:1) with $1 \mathrm{~g}$ of $\mathrm{AgSO} 4$ and titrating against ferrous ammonium sulphate taking phenanthroline as indicator (Golterman and Ohnstad, 1978). (vii) Ammonium nitrogen (NH4 $-\mathrm{N}$ ) was measured at $654 \mathrm{~nm}$, following the modified phenate method (Wetzel \& Likens, 1991) with a Shimadzu UV-visible spectrophotometer Model UV-1601 (Kyoto, Japan). (viii) The concentration of nitrite nitrogen (NO2-N) was measured at $543 \mathrm{~nm}$ in a spectrophotometer (Shimadzu, Model UV-1601, Kyoto, Japan) using $\alpha$-naphthylamine and sulphanilic acid (Wetzel \& Likens, 1991). (ix) The concentration of nitrate nitrogen (NO3-N) was determined by UV-spectrophotometric method (APHA, 1998) using aluminum hydroxide suspension and $1 \mathrm{~N} \mathrm{HCL}$ at $220 \mathrm{~nm}$ and $275 \mathrm{~nm}$ in a spectrophotometer (Shimadzu, Model UV-1601, Kyoto, Japan). The measurement of the ultraviolet absorption at $220 \mathrm{~nm}$ enabled rapid determination of nitrate nitrogen, and because dissolved organic matter may also absorb at $220 \mathrm{~nm}$, a second measurement was made at $275 \mathrm{~nm}$ to correct the nitrate nitrogen value. $(x)$ Orthophosphate (OP) content of the lake water was determined calorimetrically at $690 \mathrm{~nm}$ in a spectrophotometer (Shimadzu, ModelUV1601, Kyoto, Japan) following the stannous chloride method (APHA, 1998). (xi) Total alkalinity was determined by titration of a lake water sample with sulphuric acid (0.02 N). Alkalinity due to hydroxide and carbonate was determined to the first end point $(\mathrm{pH}$ 8.3) using phenolphthalein as indicator, and bicarbonate alkalinity was determined to the second end point $(\mathrm{pH}$ 4.5) using methyl orange (APHA, 1998). Finally, (xii) water total hardness was determined in alkaline medium with 2-3 drops of eriochrome black-T indicator, by titration against standard 0.01 Methylene diamine tetra acetic acid (EDTA) until the red wine colour of the solution turns pale blue at the end point (APHA,1998).

Analysis of physic-chemical parameters of sediment Sediment $\mathrm{pH}$ of the Chhariganga oxbow lake was measured with a potentiometer upon direct reading using a glass electrode with a saturated $\mathrm{KCl}$-calomel reference electrode (Water Resources Department, 2009). For estimation of sediment organic carbon, a 500-mg, dried, and powdered sediment sample was taken and digested with $20 \mathrm{ml}(1 \mathrm{~N}) \mathrm{K}_{2} \mathrm{Cr}_{2} \mathrm{O}_{7}$ and $20 \mathrm{ml} \mathrm{H}_{2} \mathrm{SO}_{4}$ (concentrated) then kept for 30 minutes in a dark place. The sample was then diluted with $150 \mathrm{ml}$ distilled water and $10 \mathrm{ml}$ phosphoric acid, and $1 \mathrm{ml}$ diphenylamine indicator was added to it. The sample was then titrated against $0.5 \mathrm{~N}$ ferrous ammonium sulphate (Mohr's salt) until a brilliant green colour appeared (Ghosh and Biswas, 2017d).

\section{Statistical analyses of data}

Mean, standard deviation and the degree of relationships among different physicochemical factors of water and sediment were determined using linear regression with the help of MSExcel. The level of statistical significance was accepted at $\mathrm{P}<0.05$.

\section{RESULTS AND DISCUSSION}

The physicochemical analyses of the studied oxbow lake showed the following range with annual mean values for the selected parameters: surface water temperature in ${ }^{\circ} \mathrm{C}(11-37$, 27.64 \pm 6.56$)$, water transparency in $\mathrm{cm}$ (16-106, 45.82 \pm 23.39 ), water $\mathrm{pH}(7.4-8.8,8.17 \pm 0.34)$, dissolved oxygen content $(\mathrm{DO})$ in ppm (2.60-7.85, 4.65 \pm 1.52 ), biochemical oxygen demand (BOD) in ppm (1.10-6.40, 2.98 \pm 1.59$)$, chemical oxygen demand (COD) in ppm (70-90, 79 7.38), ammonium nitrogen content $\left(\mathrm{NH}_{4}-\mathrm{N}\right)$ in ppm (0.026-0.093, 0.05 \pm 0.02$)$, nitrite nitrogen content $\left(\mathrm{NO}_{2}{ }^{-}\right.$ $\mathrm{N})$ in ppm $(0.008-0.08,0.03 \pm 0.02)$, nitrate nitrogen concentration $\left(\mathrm{NO}_{3}-\mathrm{N}\right)$ in ppm $(0-2.459,0.81 \pm 0.69)$, orthophosphate concentration (OP) in ppm (0.067-0.62, 0.26 \pm 0.18$)$, total alkalinity in ppm $(82-165,120 \pm 24.03)$, total hardness in ppm (70-138, $102.62 \pm 19.60$ ), gross primary productivity (GPP) in $\mathrm{mgC/} / \mathrm{day}$ (0.30-1.80, 1.25 \pm 0.47$)$, net primary productivity (NPP) in $\mathrm{mgC} /$ I/day (0.15-1.38, 0.95 \pm 0.40); sediment $\mathrm{pH}(6.8-7.9,7.53 \pm 0.34)$ and sediment organic carbon in \% (1.87-2.89, 2.17 \pm 0.28$)$.

The highest mean values of BOD (4.59ppm), COD (86.67ppm), OP $(0.50 \mathrm{ppm})$, sediment organic carbon (2.29\%) were observed during monsoon whereas the lowest values of oxbow lake water's transparency $(27.00 \mathrm{~cm}), \mathrm{pH}(7.84), \mathrm{DO}(3.63 \mathrm{ppm})$ and $\mathrm{NO}_{2}-\mathrm{N}(0.01 \mathrm{ppm})$ contents were found during monsoon when jute retting process gets intensified in the oxbow lake (Tables 2 and 3). Compared to their values in pre-monsoon, mean values in monsoon showed an increase in BOD (182.57\%), COD (18.18\%), $\mathrm{NH}_{4}-\mathrm{N}$ (7.87\%), $\mathrm{NO}_{3}-\mathrm{N}(17.73 \%)$ and OP content (167.64\%) while reduction in water transparency $(62.54 \%), \mathrm{pH}$ (5.74\%), DO (22.16\%), $\quad \mathrm{NO}_{2}-\mathrm{N}$ (65.68\%), total hardness (21.63\%), total alkalinity (24.27\%), GPP and NPP (both reduced by about $50 \%$ ); sediment organic carbon content (10.11\%) and $\mathrm{pH}$ values (7.36\%). The highest mean values of water $\mathrm{pH}(8.42$, increased by $7.30 \%$ ), DO (5.96 ppm, increased by $64.52 \%$ ), $\mathrm{NH}_{4}^{-}$ $\mathrm{N}(0.07 \mathrm{ppm}$, increased by $88.21 \%), \mathrm{NO}_{3}-\mathrm{N}(1.15 \mathrm{ppm}$, increased by $83.12 \%)$ and sediment $\mathrm{pH}(7.80)$ were observed with the low- 
est mean values of oxbow lake water's temperature $\left(19.56^{\circ} \mathrm{C}\right)$, OP $(0.13 \mathrm{ppm}$, decreased by $73.53 \%)$, total hardness $(85.25$ ppm, decreased by $12.17 \%$ ) and total alkalinity $(98.67 \mathrm{ppm}$, decreased by $11.76 \%$ ) whereas changes also observed in $\mathrm{NO}_{2}-\mathrm{N}$ content (115.34\% increase), COD (10.58\% decrease), BOD 1 (47.70\% decrease), transparency (increased by $49.23 \%$ ) and sediment's organic carbon content (5.54\% decrease) during post -monsoon compared to previous season. During pre-monsoon highest mean values were observed for water transparency $(72.07 \mathrm{~cm}$, further increased by $78.87 \%)$, water temperature $\left(31.5^{\circ} \mathrm{C}\right.$, about $61 \%$ increase), total hardness (123.86 ppm, $45.29 \%$ increase) and total alkalinity (147.64 ppm, 49.64\% up) and lowest values observed for sediment $\mathrm{pH}$ (7.14, decreased by $8.42 \%)$, sediment organic carbon (2.08\%, decreased by $3.86 \%)$, $\mathrm{BOD}_{1}$ (1.63 ppm, 32.33\% fall), COD (73.33 ppm, 5.38\% decrease), $\mathrm{NO}_{3}-\mathrm{N}(0.53 \mathrm{ppm}, 53.62 \%$ decrease) with changes in DO (21.91\% fall), $\mathrm{NH}_{4}-\mathrm{N}$ (50.75\% fall) and $\mathrm{NO}_{2}-\mathrm{N}$ (35.31\% up), OP ( $41.17 \%$ up) if compared to post-monsoon of the study period. The highest concentration of $\mathrm{NH}_{4}-\mathrm{N}$ and $\mathrm{NO}_{3}-\mathrm{N}$ were noticed during post-monsoon and OP during monsoon. The water transparency mean values showed sharp fall during monsoon from pre-monsoon. Physico-chemical analyses revealed that almost all parameters in oxbow lake did not show significant changes throughout the year unlike water transparency, $\mathrm{BOD}_{1}, \mathrm{NO}_{2}$ and especially OP content of water which have otherwise shown significant changes throughout the year (Figure 1).

Present observed temperature data are concurrent with the several other studies which have demonstrated narrow amplitude of variation showing the characteristic of tropical environment (Obire et al., 2003; Chindah et al. 2005; Hart and Zabbey, 2005; Sikoki and Zabbey, 2006). Present results are also in full or partial agreement with others studies (Joadder, 2009; Joo and David, 1995, Das et al., 2011a; Ziauddin et al., 2013; Feresin et al., 2010; Biswasroy et al., 2011; Das et al., 2009). However, the annual average range of water temperature of the studied oxbow lake indicates its suitability for fish habitat and breeding. The mean values of water transparency showed sharp fall during monsoon compared to pre-monsoon indicating high total solid concentrations due to loading of heavy organic matter restricting light penetration into oxbow lake water. This resulted in decrease in oxygen production owing to reduced rate of photosynthesis. This is accentuated by huge jute retting processes in the lake during monsoon. Present results showed quite similarity with other studies (Joadder, 2009; Feresin et al., 2010; Das et al., 2011a). Just contrary to the study (Ziauddin et al., 2013) present findings on Secchi disc transparency showed peak in pre-monsoon and fall during monsoon. Jute retting and inflowing water during monsoon make all the differences in present case. The higher annual average range of water transparency rendered fish habitat and growth in the studied oxbow lake not conducive as the transparency of productive water bodies should be $40 \mathrm{~cm}$ or less to be considered as suitable for aquatic life when the maximum values of the Secchi depth are usually associated with the lowest mean hydrometric levels (Banerjea,
1967).

The $\mathrm{pH}$ of the present lake varied (7.4 to 8.8 ) a great deal during the year, though always falling on the alkaline side. The seasonal variation is attributed to photosynthetic activity as was seen larger during post-monsoon and pre-monsoon resulting in a better utility of carbon sources and an associated decrease in hydrogen-ion concentration (Zutshi et al., 1972). Present results showed similarity with other studies (Zutshi et al., 1980; Trisal, 1985; Joo and David, 1995; Joadder, 2009; Das et al., 2009; Feresin et al., 2010; Biswasroy et al., 2011; Das et al., 2011a; Ziauddin et al., 2013). We observed highest water $\mathrm{pH}$ during jute retting season on monsoon in contrast to the study (Das et al., 2011). The $\mathrm{pH}$ range of the present oxbow lake throughout the year may attribute low to medium trophic status of the studied water body that supported moderate number of species.

One of the most important abiotic factors influencing life in aquatic ecosystem is the dissolved oxygen. Its depletion perhaps is the most critical manifestation of pollution. The overall variation in dissolved oxygen (2.6-7.85) in present study indicate very low levels of dissolved oxygen during extreme monsoon but DO value increased in subsequent period to attain satisfactory saturation in post-monsoon. The observed dissolved oxygen values were somewhat below the range of the other studies (Patil and Panda, 1986; Koliyar and Rokhare, 2008). But like present findings higher DO concentrations in post-monsoon were also observed (McNeely et al., 1979, Joo and David, 1995; Joadder, 2009; Das et al., 2009, 2011a; Ziauddin et al., 2013). Quite similar DO range like present findings was also in an oxbow lake in Nadia district (Biswasroy et al., 2011). The annual average DO value indicates unproductiveness and poor ecosystem heath of the studied oxbow lake and was always slightly on lower side throughout the year. This indicates immediate threat of pollution especially due to jute retting during monsoon when compared to the rest of the year.

The values of the biochemical oxygen demand (BOD) in the present study ranged from 1.10 to $6.40 \mathrm{ppm}$ with the annual mean of $2.98 \pm 1.59 \mathrm{ppm}$. Like present findings BOD values were observed quite similar (Das et al. 2009; Srinivasan, 1967; Biswasroy et al., 2011) and BOD was seen increased during jute retting during monsoon (Dasgupta et al., 2006; Ghosh and Biswas, 2015c). High BOD values are generally associated with anoxic conditions and low community diversity of fish and shell fish in coconut husk retting zones (Nandan, 1997). By contrast, it was also reported (Dasgupta et al., 2006) that jute retting has dual effects also as it creates anaerobic condition for fish mortality for a short period and releases nutrients with the passage of time to help the growth of the aquatic life. But jute retting impacted significantly on native fish diversity and aquatic health parameter including $\mathrm{BOD}_{1}$ and transparency (Ghosh and Biswas, 2015c) like the present study. However, higher BOD values in the present study indicate moderate pollution especially during monsoon compared to other seasons. The significantly higher increase in BOD values during monsoon is attributed to organic loading from jute retting and surface run off from neighbouring agricultural areas. The COD concentra- 
Table 1. Data synopsis of the Chhariganga oxbow lake ecosystem.

\begin{tabular}{|c|c|c|c|c|c|}
\hline Oxbow lake's Attributes & PRM & MON & POM & YR Average & YR Total \\
\hline RAW (ha) & 58.28 & 58.28 & 58.28 & 58.28 & 58.28 \\
\hline RAW (sqm) & 582800 & 582800 & 582800 & 582800 & 582800 \\
\hline Average Length (m) & 2500 & 2500 & 2500 & 2500 & 2500 \\
\hline Average Width (m) & 80 & 200 & 120 & 133 & 133 \\
\hline EWSA (sqm) & 200000 & 500000 & 300000 & 333333 & 333333 \\
\hline EWSA (ha) & 20 & 50 & 30 & 33.33 & 33.33 \\
\hline Average Depth (ft) & 7 & 10 & 8.5 & 8.50 & 8.50 \\
\hline Average Depth (m) & 2.1 & 3.0 & 2.55 & 2.55 & 2.55 \\
\hline Volume of EWSA $\left(\mathrm{m}^{3}\right)$ & 420000 & 1500000 & 765000 & 850000 & 895000 \\
\hline Volume of RAW $\left(\mathrm{m}^{3}\right)$ & 1223880 & 1748400 & 1486140 & 1486140 & 1486140 \\
\hline Volume of EWSA (million ton) & 0.42 & 1.50 & 0.77 & 0.85 & 0.90 \\
\hline Jute retting units & - & 600 & - & 600 & 600 \\
\hline Jute retting area per unit (sqm) & - & 30 & - & 30 & 30 \\
\hline Jute retting Total area (sqm) & - & 18000 & - & 18000 & 18000 \\
\hline Jute retting area (ha) & - & 1.80 & - & 1.80 & 1.80 \\
\hline Jute retting area \% EWSA & - & 3.60 & - & 5.40 & 5.40 \\
\hline Jute retting area \% RAW & - & 3.09 & - & 3.09 & 3.09 \\
\hline volume of water for jute retting $\left(\mathrm{m}^{3}\right)$ & - & 54000 & - & 45900 & 45900 \\
\hline Water required (\%) of EWSA for jute retting & - & 3.60 & - & 5.40 & 5.13 \\
\hline Water required (\%) of RAW for jute retting & - & 3.09 & - & 3.09 & 3.09 \\
\hline
\end{tabular}

EWSA=Effective water spread area, RAW=Recorded area of water body, $\mathrm{PRM}=$ Premonsoon, $\mathrm{MON}=$ Monsoon, POM=Postmonsoon, $(-)=$ No jute retting seen.

Table 2. Seasonal variations in water parameters and changes compared to previous season.

\begin{tabular}{|c|c|c|c|c|c|c|c|c|c|c|c|c|c|c|}
\hline \multirow{3}{*}{$\begin{array}{l}\text { Season } \\
\text { Parameter } \\
\text { Temperature } \\
\left(\mathrm{T}^{\circ} \mathrm{C}\right)\end{array}$} & \multicolumn{2}{|c|}{ PRM } & \multicolumn{2}{|c|}{ MON } & \multicolumn{2}{|c|}{ POM } & \multicolumn{2}{|c|}{ Year } & \multirow{3}{*}{$\begin{array}{l}\text { PRM } \\
61.06\end{array}$} & \multirow{3}{*}{$\begin{array}{r}\text { MON } \\
\% c \\
-3.73\end{array}$} & \multirow{3}{*}{$\frac{\text { POM }}{\text { ange }}$} & \multirow{2}{*}{\multicolumn{2}{|c|}{$\begin{array}{c}\text { Year } \\
\text { Min }\end{array}$}} & \multirow{3}{*}{$\frac{\text { Max }}{37}$} \\
\hline & \multirow{2}{*}{$\frac{M}{31.50}$} & \multirow{2}{*}{$\frac{\text { SD }}{4.20}$} & \multirow{2}{*}{$\frac{M}{30.33}$} & \multirow{2}{*}{$\frac{\mathrm{SD}}{1.83}$} & \multirow{2}{*}{$\frac{M}{19.56}$} & \multirow{2}{*}{$\frac{\text { SD }}{5.84}$} & \multirow{2}{*}{$\frac{M}{27.64}$} & \multirow{2}{*}{$\frac{S D}{6.56}$} & & & & & & \\
\hline & & & & & & & & & & & & 21.82 & 11 & \\
\hline $\begin{array}{l}\text { Transparency } \\
(\mathrm{cm})\end{array}$ & 72.07 & 21.03 & 27.00 & 7.53 & 40.29 & 3.77 & 45.82 & 23.39 & 78.87 & -62.54 & 49.23 & 65.57 & 16 & 106 \\
\hline $\mathrm{pH}$ & 8.32 & 0.18 & 7.84 & 0.27 & 8.42 & 0.20 & 8.17 & 0.34 & -1.13 & -5.74 & 7.30 & 0.43 & 7.4 & 8.8 \\
\hline DO (ppm) & 4.67 & 0.34 & 3.63 & 1.19 & 5.98 & 1.77 & 4.65 & 1.52 & -21.91 & -22.16 & 64.52 & 20.45 & 2.6 & 7.85 \\
\hline $\mathrm{BOD}_{1}(\mathrm{ppm})$ & 1.63 & 0.37 & 4.59 & 1.34 & 2.40 & 0.53 & 2.98 & 1.59 & -32.33 & 182.57 & -47.70 & 102.54 & 1.1 & 6.4 \\
\hline COD (ppm) & 73.33 & 5.77 & 86.67 & 5.77 & 77.50 & 5.00 & 79.00 & 7.38 & -5.38 & 18.18 & -10.58 & 2.23 & 70 & 90 \\
\hline $\mathrm{NH}_{4}-\mathrm{N}(\mathrm{ppm})$ & 0.03 & 0.01 & 0.03 & 0.01 & 0.07 & 0.02 & 0.05 & 0.02 & -50.75 & 7.87 & 88.21 & 45.34 & 0.026 & 0.093 \\
\hline $\mathrm{NO}_{2}-\mathrm{N}(\mathrm{ppm})$ & 0.04 & 0.01 & 0.01 & 0.01 & 0.03 & 0.03 & 0.03 & 0.02 & 35.31 & -65.68 & 115.34 & 84.97 & 0.008 & 0.080 \\
\hline $\mathrm{NO}_{3}-\mathrm{N}(\mathrm{ppm})$ & 0.53 & 0.09 & 0.63 & 0.13 & 1.15 & 1.06 & 0.81 & 0.69 & -53.62 & 17.73 & 83.12 & 47.24 & 0.000 & 2.459 \\
\hline $\mathrm{OP}(\mathrm{ppm})$ & 0.19 & 0.05 & 0.50 & 0.11 & 0.13 & 0.06 & 0.26 & 0.18 & 41.17 & 167.64 & -73.53 & 135.27 & 0.067 & 0.620 \\
\hline Total & & & & & & & & & & & & & & \\
\hline $\begin{array}{l}\text { Alkalinity } \\
\text { (ppm) }\end{array}$ & 147.64 & 13.12 & 111.81 & 11.91 & 98.67 & 13.76 & 120.00 & 24.03 & 49.64 & -24.27 & -11.76 & 13.61 & 82 & 165 \\
\hline Total & & & & & & & & & & & & & & \\
\hline $\begin{array}{l}\text { Hardness } \\
\text { (ppm) }\end{array}$ & 123.86 & 11.50 & 97.06 & 9.79 & 85.25 & 14.03 & 102.62 & 19.60 & 45.29 & -21.63 & -12.17 & 11.48 & 70 & 138 \\
\hline $\begin{array}{l}\text { Gross } \\
\text { Primary }\end{array}$ & & & & & & & & & & & & & & \\
\hline $\begin{array}{l}\text { Productivity } \\
\text { (GPP) (mgC/l/ } \\
\text { day) }\end{array}$ & 1.66 & 0.17 & 0.84 & 0.37 & 1.32 & 0.37 & 1.25 & 0.47 & 25.68 & -49.70 & 58.18 & 34.16 & 0.30 & 1.80 \\
\hline $\begin{array}{l}\text { Net Primary } \\
\text { Productivity } \\
\text { (NPP) (mgC/l/ } \\
\text { day) }\end{array}$ & 1.26 & 0.10 & 0.61 & 0.37 & 1.04 & 0.32 & 0.95 & 0.40 & 20.94 & -51.35 & 69.96 & 39.55 & 0.15 & 1.38 \\
\hline
\end{tabular}

$\mathrm{M}=$ Mean value, $\mathrm{SD}=$ Standard deviation, $\mathrm{PRM}=$ Pre-monsoon, $\mathrm{MON}=$ Monsoon, $\mathrm{POM}=$ Post-monsoon.

Table 3. Seasonal variations in Chhariganga oxbow lake sediment quality parameters and changes compared to previous season.

\begin{tabular}{lcccccccccccccc}
\hline Season & \multicolumn{2}{c}{ PRM } & \multicolumn{2}{c}{ MON } & \multicolumn{2}{c}{ POM } & \multicolumn{2}{c}{ Year } & PRM & MON & POM & & Year \\
\hline Parameter & M & SD & M & SD & M & SD & M & SD & & \% change & & Min & Max \\
\hline Sediment pH & 7.14 & 0.26 & 7.67 & 0.18 & 7.80 & 0.09 & 7.53 & 0.34 & -8.42 & 7.36 & 1.71 & 0.65 & 6.8 & 7.9 \\
$\begin{array}{l}\text { Sediment Org. C } \\
(\%)\end{array}$ & 2.08 & 0.02 & 2.29 & 0.54 & 2.16 & 0.07 & 2.17 & 0.28 & -3.86 & 10.11 & -5.54 & 0.71 & 1.87 & 2.89 \\
\hline
\end{tabular}

$\mathrm{M}=$ Mean value, $\mathrm{SD}=$ Standard deviation, $\mathrm{PRM}=$ Pre-monsoon, $\mathrm{MON}=$ Monsoon, $\mathrm{POM}=$ Post-monsoon. 
Table 4. Correlation coefficients of Chhariganga oxbow lake water and sediment quality parameters.

\begin{tabular}{|c|c|c|c|c|c|c|c|c|c|c|c|c|c|c|c|}
\hline Indicator & $\mathrm{SpH}$ & SOC & $\mathrm{Tr}$ & $\mathrm{WpH}$ & $\mathrm{T}^{\circ} \mathrm{C}$ & DO & BOD & COD & $\mathrm{NH}_{4}-\mathrm{N}$ & $\mathrm{NO}_{2}-\mathrm{N}$ & $\mathrm{NO}_{3}-\mathrm{N}$ & OP & $\mathrm{TH}$ & TA & GPP \\
\hline SOC & 0.67 & & & & & & & & & & & & & & \\
\hline $\operatorname{Tr}$ & -0.89 & -0.94 & & & & & & & & & & & & & \\
\hline $\mathrm{WpH}$ & -0.18 & -0.85 & 0.61 & & & & & & & & & & & & \\
\hline $\mathrm{T}^{\circ} \mathrm{C}$ & -0.72 & 0.03 & 0.32 & -0.56 & & & & & & & & & & & \\
\hline DO & 0.25 & -0.54 & 0.22 & 0.91 & -0.86 & & & & & & & & & & \\
\hline BOD & 0.56 & 0.99 & -0.88 & -0.92 & 0.18 & -0.66 & & & & & & & & & \\
\hline COD & 0.60 & 1.00 & -0.90 & -0.89 & 0.12 & -0.62 & 1.00 & & & & & & & & \\
\hline $\mathrm{NH}_{4}-\mathrm{N}$ & 0.70 & -0.05 & -0.30 & 0.57 & -1.00 & 0.86 & -0.20 & -0.14 & & & & & & & \\
\hline $\mathrm{NO}_{2}-\mathrm{N}$ & -0.67 & -1.00 & 0.94 & 0.85 & -0.03 & 0.54 & -0.99 & -1.00 & 0.05 & & & & & & \\
\hline $\mathrm{NO}_{3}-\mathrm{N}$ & 0.75 & 0.02 & -0.37 & 0.51 & -1.00 & 0.82 & -0.12 & -0.07 & 1.00 & -0.02 & & & & & \\
\hline OP & 0.19 & 0.86 & -0.63 & -1.00 & 0.54 & -0.90 & 0.92 & 0.90 & -0.56 & -0.86 & -0.50 & & & & \\
\hline $\mathrm{TH}$ & -0.99 & -0.59 & 0.83 & 0.06 & 0.79 & -0.36 & -0.46 & -0.51 & -0.78 & 0.59 & -0.82 & -0.08 & & & \\
\hline TA & -1.00 & -0.62 & 0.85 & 0.11 & 0.77 & -0.32 & -0.49 & -0.54 & -0.75 & 0.62 & -0.80 & -0.12 & 1.00 & & \\
\hline GPP & -0.69 & -1.00 & 0.94 & 0.84 & -0.01 & 0.53 & -0.99 & -0.99 & 0.03 & 1.00 & -0.04 & -0.85 & 0.60 & 0.63 & \\
\hline NPP & -0.62 & -1.00 & 0.91 & 0.88 & -0.10 & 0.60 & -1.00 & -1.00 & 0.12 & 1.00 & 0.04 & -0.89 & 0.53 & 0.56 & 1.00 \\
\hline
\end{tabular}

PRM=Pre-monsoon, MON=Monsoon, POM=Post-monsoon, SpH=Sediment $\mathrm{pH}$, SOC=Sediment organic carbon (\%), Tr=Transparency (cm), $\mathrm{WpH}=$ Water $\mathrm{pH}, \mathrm{TH}=$ Total Hardness (ppm), TA=Total alkalinity (ppm), GPP/NPP=Gross/Net primary productivity $\left(\mathrm{gC} / \mathrm{m}^{3} / \mathrm{d}\right)$.

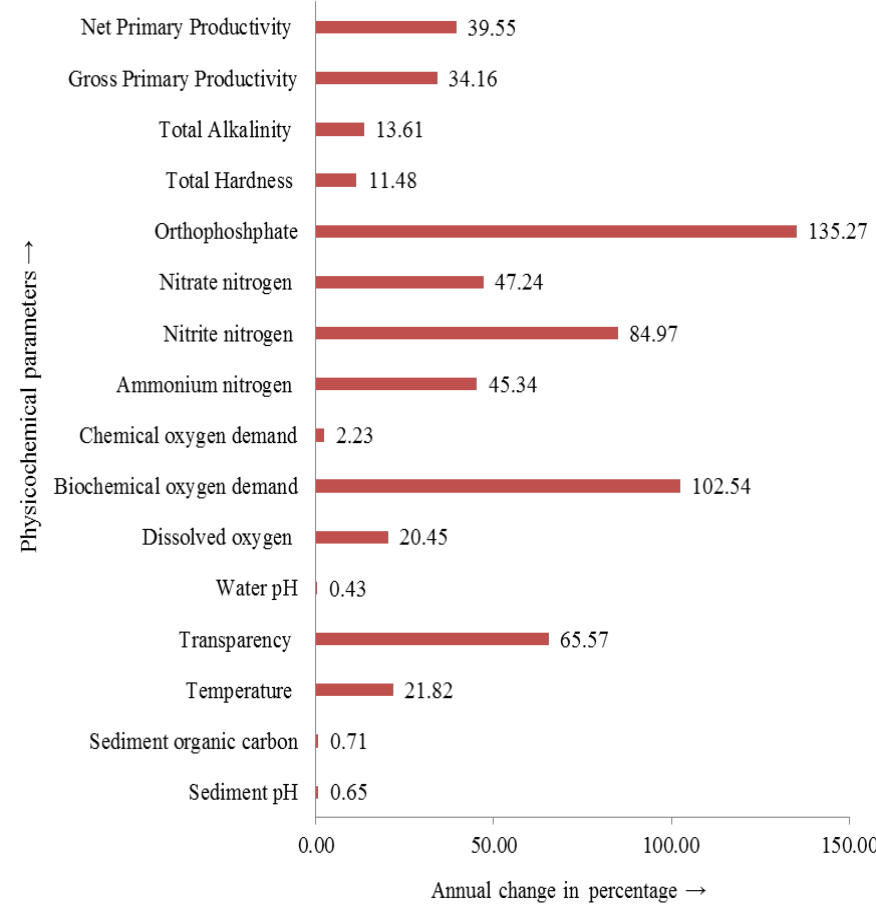

Figure 1. Annual changes of physicochemical parameters.

tion generally ranges from $20 \mathrm{mg} / \mathrm{l}$ or less in unpolluted waters to greater than $200 \mathrm{mg} / \mathrm{l}$ in waters receiving industrial effluents (Geocities, 2009). Quite higher COD range of 32-182 mg/l was also reported (Koliyar and Rokhare, 2008). The higher increase in COD (range 70-90 ppm) values in the present study during jute retting period indicates moderate pollution status of the lake especially during monsoon compared to the rest of the year. Present finding of quite low range $(0.026-0.093 \mathrm{mg} / \mathrm{l})$ of ammonium nitrogen level, even under high organic loading condition, has been due to prevailing nitrification process over denitrifica- tion process, in comparison with other studies (Joo and David, 1995; Joadder, 2009; Feresin et al., 2010). Lower nitrite nitrogen values were observed in the present study compared to other studies (Das et al., 2009; Joadder, 2009). Present study noted higher nitrate nitrogen values due to higher rate of nitrification compared to other studies (Joo and David, 1995; Feresin et al., 2010; Das et al., 2009, 2011a; Ziauddin et al., 2013). The present findings on orthophosphate content are concurrent with other studies (Joo and David, 1995; Das et al., 2009; Feresin et al., 2010). However, we found bit higher orthophosphate values compared to other studies (Vass and Zutshi, 1979; Das et al., 2011a; Biswasroy et al., 2011; Ziauddin et al., 2013). On the basis of orthophosphate concentrations observed the studied water body may be categorized into oligo to mesotrophic oxbow lake as per different trophic categories as stated by Wetzel (1983). As for any productive water, the N/P ratio should range from 4:1 to $10: 1$ (Jhingran, 2002), present finding of the N/P ratio $(0.51: 1$ to $4.24: 1)$ was not so conducive for fish productivity.

Alkalinity values (range $82-165 \mathrm{mg} / \mathrm{l}$, year mean $120 \pm 24.03 \mathrm{mg}$ / I) of the present study are in tune with the result of Trisal (1985) in contrast with other reports (Zutshi et al., 1972; Joo and David, 1995; Das et al., 2009, 2011a; Joadder, 2009; Feresin et al., 2010; Ziauddin et al., 2013). Jute retting causes increase in the alkalinity and water becomes richer in nutrients with higher concentrations of alkalinity (Saha et al., 1999) and the water bodies should have total alkalinities of $200-300 \mathrm{mg} / \mathrm{l}$ for successful fish culture (Boyd, 1992). The increased level of alkalinity in the present study has been due to high rate of photosynthesis and primary productivity in the oxbow lake ecosystem, particularly when subjected to high organic loading arising from 
the jute retting and increased nutrient rich surface run off. The alkalinity concentration of the studied oxbow lake indicated its moderate nutrient richness. The present observed values (70$138 \mathrm{mg} / \mathrm{l}$ ) of total hardness clearly showed a soft to moderately hard water characteristics (Moyle, 1945) of the oxbow lake. High hardness values were observed with maximum in premonsoon and minimum in post-monsoon like other studies (Koliyar and Rokhare, 2008; Das et al., 2011; 2011a; Ziauddin et al., 2013) unlike the studies (Das et al., 2009; Joadder, 2009). Slight higher hardness values attribute the present oxbow lake water as moderate in nutrient richness and fish culture.

We found GPP range of 25-150 with an annual mean of $104.07 \pm 39.17) \mathrm{mgC} / \mathrm{m}^{3} / \mathrm{h}$ and NPP range of $12.5-115.0$ with year mean of $79.44 \pm 33.48) \mathrm{mgC} / \mathrm{m}^{3} / \mathrm{h}$. The range of GPP values have been reported as low as $4-5 \mathrm{mgC} / \mathrm{m}^{2} /$ day to $2600-2700$ $\mathrm{mgC} / \mathrm{m}^{2} /$ day with an annual mean of $847.5 \mathrm{mgC} / \mathrm{m}^{2} /$ day (Olive et al., 1968) while the NPP values were reported to range from 34 to $2459 \mathrm{mgC} / \mathrm{m}^{3} / \mathrm{h}$ with mean of $725 \pm 729 \mathrm{mgC} / \mathrm{m}^{3} / \mathrm{h}$ (Joo and David, 1995). The results of the present study are within the limit (Srinivasan, 1967; Olive et al., 1968). The results of the present study have quite lower NPP compared to the findings of Joo and David (1995) and lower GPP compared to another finding of Feresin et al. (2010).

Almost similar sediment organic carbon content and a sediment $\mathrm{pH}$ like present results are observed in the Arpara Beel, an oxbow lake adjacent to the oxbow lake under study at Nakashipara Block in Nadia district (Bala and Mukherjee, 2011) but present results are considerably higher compared to other result in Assam oxbow lakes (Das et al., 2011a) which are due to geographical and other differences. However, the annual average value of sediment's $\mathrm{pH}$ and organic carbon content of the studied oxbow lake indicate its nutrient richness. The COD was observed to be strongly correlated with sediment organic carbon content (SOC) and BOD, (Table 4) but was inversely correlated with $\mathrm{NO}_{2}-\mathrm{N}$ and NPP. Nitrogen species like nitrate nitrogen and ammonium nitrogen were found to be inversely related to water temperature whereas orthophosphate was inversely correlated with water $\mathrm{pH}$. However, strong correlations were noticed in $\mathrm{NO}_{2}-\mathrm{N}$ with primary productivity, $\mathrm{NH}_{4}$ with $\mathrm{NO}_{3}-\mathrm{N}$, total alkalinity and hardness, and GPP with NPP.

In present study on oxbow lake, we found strong correlation between sediment organic content and COD; BOD and COD; water ammonium nitrogen and water nitrate nitrogen content; total hardness and alkalinity content; GPP and NPP. Similarly significantly positive correlations were also found between water BOD and sediment organic content; nitrate nitrogen and DO; orthophosphate and sediment organic content/COD/BOD; transparency and hardness/alkalinity; transparency/water $\mathrm{pH}$ and water GPP/NPP. But present results also clearly demonstrated inverse correlation between water temperature and water ammonium nitrogen content; sediment organic content and water nitrite nitrogen; COD and nitrite nitrogen content; water temperature and nitrate nitrogen content; water $\mathrm{pH}$ and orthophosphate content; sediment $\mathrm{pH}$ and water total alkalinity; sediment organic content and GPP/NPP; and BOD/COD and NPP.
Similarly significantly inverse correlations were also found between orthophosphate and nitrite nitrogen /DO content; alkalinity and nitrate nitrogen; and GPP and BOD/COD/orthophosphate.

The results on correlation coefficients corroborate the study of Edward et al. (2014) in terms of the following physicochemical parameters: water $\mathrm{pH}$ with temperature, alkalinity, DO, transparency, $\mathrm{OP}, \mathrm{NO}_{3}-\mathrm{N}$; temperature with alkalinity, $\mathrm{DO}$, transparency, $\mathrm{NO}_{3}-\mathrm{N}$; DO with $\mathrm{NO}_{3}-\mathrm{N}$; transparency with $\mathrm{OP}, \mathrm{NO}_{3}-\mathrm{N}$; and OP with $\mathrm{NO}_{3}$ and also the findings of Mbalassa et al. (2014) in terms of water temperature with transparency; $\mathrm{DO}$ with $\mathrm{pH}$, transparency; and $\mathrm{pH}$ with transparency. In general analyses of physicochemical parameters, compared to their values in premonsoon, the mean monsoon values were increased in sediment organic carbon content, BOD and COD. The increases may be due to jute retting and inflowing higher organic matters. The highest concentration of $\mathrm{NH}_{4}-\mathrm{N}$ and $\mathrm{NO}_{3}-\mathrm{N}$ during postmonsoon and OP during monsoon in the present study may be also due to the allochthonous organic input and the decomposition of the aquatic macrophytes and jute retting. The sharp fall in mean values of water transparency during monsoon compared to pre-monsoon indicated high level of total dissolved solids due to heavy organic matter load restricting light penetration into oxbow lake. Consequently concentration of dissolved oxygen decreases due to reduced rate of photosynthesis. Significant changes in water transparency, BOD, and OP content of water in the present study are attributed to overall organic pollution in oxbow lake throughout the year in general, and during monsoon, in particular.

The present discussion on the physic-chemical study indicate that the high values of parameters like $\mathrm{pH}$, Secchi disc transparency, total hardness, total alkalinity, orthophosphate and low values of DO, BOD, COD, N/P ratio, GPP and NPP showed the present semi-closed oxbow lake water of poor to moderate quality and it may be classified as oligo-mesotrophic in nutrient status with high to moderate organic pollution due to jute retting. The poor health status assessed with the physicochemical properties does also corroborate with the findings of the studies on the same oxbow lake assessed with rotifer diversity indices (Ghosh and Biswas, 2014), zooplankton diversity indices (Ghosh and Biswas, 2015a), macrophytes diversity (Ghosh and Biswas, 2015d), phytoplankton diversity (Ghosh and Biswas, 2015e), fish diversity (Ghosh and Biswas, 2017a; 2017c), fish productivity (Ghosh and Biswas, 2017b) during the same period of study on the same oxbow lake.

\section{Conclusion}

The present study concluded that jute retting contributed moderate pollution status of the lake especially during monsoon compared to the rest of the year. The results showed the highest mean values of BOD (4.59ppm), COD (86.67ppm), OP (0.50ppm), sediment organic carbon (2.29\%)were observed during monsoon whereas the lowest values of oxbow lake water's transparency $(27.00 \mathrm{~cm}), \mathrm{pH}(7.84), \mathrm{DO}(3.63 \mathrm{ppm})$ and $\mathrm{NO}_{2}-\mathrm{N}$ $(0.01 \mathrm{ppm})$ contents were found during monsoon when jute 
retting process gets intensified in the oxbow lake. GPP was recorded in the range of 25-150 (with an annual mean of $104.07 \pm 39.17$ ) $\mathrm{mgC} / \mathrm{m}^{3} / \mathrm{h}$ and NPP range of $12.5-115.0$ (with year mean of $79.44 \pm 33.48) \mathrm{mgC} / \mathrm{m}^{3} / \mathrm{h}$. Positive correlations were found between sediment organic content and COD; BOD and COD; water ammonium nitrogen and water nitrate nitrogen content; total hardness and alkalinity; GPP and NPP. Similarly significantly positive correlations were also found between water BOD and sediment organic content; nitrate nitrogen and DO; orthophosphate and sediment organic content/COD/BOD; transparency and hardness/alkalinity; transparency/water $\mathrm{pH}$ and water GPP/NPP. The present semi-closed oxbow lake water was of poor to moderate quality and it was classified as oligo -mesotrophic in nutrient status with high to moderate organic pollution due to jute retting process which needs to be controlled and regulated for sustainable aquaculture in oxbow lake ecosystem.

\section{ACKNOWLEDGEMENT}

Authors acknowledge the facilities of research provided by the Department of Ecological Studies of University of Kalyani; Department of Fisheries of Govt. of West Bengal and Kutirpara Fishermen Co-operative Society Ltd. of Nakashipara Dev. Block, Nadia, West Bengal, India.

Open Access: This is open access article distributed under the terms of the Creative Commons Attribution License, which permits unrestricted use, distribution, and reproduction in any medium, provided the original author(s) and the source are credited.

\section{REFERENCES}

American Public Health Association APHA, (1998).Standard methods for the examination of water and wastewater, 20th ed. Clesceri LS, Greenberg AE, \& Eaton, AD, (Eds.); American Public Health Association: Washington, DC.

Aswathi, U. and Tiwari, S. (2004). Seasonal trends in abiotic factors of a lentic habitat (Govindgarh Lake) Rewa, M.P, India. Journal of Ecology, Environment and Conservation, 10 (2): 65-170.

Bala, G. and Mukherjee, A. (2011). Physicochemical properties of sediments and their role in the production process of some wetlands of Nadia District, West Bengal. Journal of Environment and Sociobiology, 8(2):253-256.

Banerjea, S.M. (1967). Water quality and soil condition of fish ponds in some states of India in relation to fish production. Indian Journal of Fisheries, 14 (1 and 2): 115-144.

Biswasroy, M., Samal, N.R., Roy, P.K. and Mazumdar, A. (2011). Watershed management with emphasis on fresh water wet land: A case study of a flood plain wetland in West Bengal, India. Global Nest Journal, 13(1): 1-10.

Boyd, C.E. (1992). Water quality management for pond fish culture. Elsevier Scientific Publishing Company, Oxford, pp. 318.

Chandrasekhar, J.S., Lenin Babu, K. and Somasekhar, R.K. (2003).
Impact of urbanization on Bellandur Lake, Bangalore - A case study. Journal of Environmental Biology, 24(3):223-227.

Chindah, A.C., Braide, S.A. and Onwuteaka, J.N. (2005). Vertical distribution of periphyton on woody substrate in a brackish wetland embayment of Bonny River, Niger Delta. Niger Delta Biologia, 5(11): 97-108.

Das, B., Tripathy, S., Chakraborty, A. and Chakrabarti, K. (2011). Studies on physico-chemical and microbiological parameters of water samples before and after jute retting. Journal of Biological Sciences, 11(2): 201-215

Das, S.K., Biswas, D. and Roy, S. (2009). Study of Hydrophytes in some lentic water bodies in West Bengal, India. Ecoprint, 16:9-13.

Das, S.K., Gogoi, N.M. and Dana, S.S. (2011a). Status of aquaculture and management practices of the primarily unmanaged ox-bow lakes (Beels) of Sivasagar and Jorhat districts of Assam, Indian Journal of Fisheries, 58(2): 107-113.

Dasgupta, M., Goswamy, S. and Goswamy, A. (2006). Effect of jute retting on the physic-chemical and biological condition of water. Indian Journal of Fisheries, 53(4):455-457.

Edward, J.B., Idowu, E.O., Oso, J.A. and Kadri, M.I. (2014). Fish productivity of ado-ekiti water reservoir in relation to physicochemical characteristics and mopho-edaphic index, International Journal of Multidisciplinary Research and Development, 1(1):11-17.

Feresin, E.G., Arcifa, M.S., Silva, L.H.S.D. and Esguícero, A.L.H. (2010). Primary productivity of the phytoplankton in a tropical Brazilian shallow lake: experiments in the lake and in mesocosms. Acta Limnologica Brasiliensia, 22(4):384-396, doi: 10.4322/actalb.2011.004

Gaarder, T. and Gran, H.H. (1927). Investigation of the production of phytoplankton in the Oslo, Fjord. Rapp. E and Proc. Verb. Cons. Internet. Explor. Mer., 42:1-48.

Ghosh. D. and Biswas, J.K. (2014). Rotifera Diversity Indices: Assessment of Aquatic Health of an Oxbow lake ecosystem in West Bengal. International Journal of Current Research. 6 (12):10554-10557.

Ghosh, D. and Biswas, J.K. (2015a). Zooplankton Diversity Indices: Assessment of an Ox-Bow Lake Ecosystem for Sustainable Management in West Bengal. International Journal of Advanced Biotechnology and Research (IJBR), 6(1):37-43.

Ghosh, D. and Biswas, J.K. (2015b). Macroinvertebrates' diversity indices: quantitative bio-assessment of ecological health status of an ox-bow lake in eastern India. Journal of Advances in Environmental Health Research, 3(2): 78-90.

Ghosh, D. and Biswas, J.K. (2015c). Impact of Jute Retting on Native Fish Diversity and Aquatic Health of Roadside Transitory Water Bodies: An Assessment in Eastern India, Journal of Ecological Engineering, 16(4): 14-21, DOI: $10.12911 / 22998993 / 59342$

Ghosh, D. and Biswas, J.K. (2015d). Biomonitoring macrophytes and abundance for rating aquatic health of an oxbow lake ecosystem in Ganga River basin. American Journal of Phytomedicine and Clinical Therapeutics, 3(10): 602-621.

Ghosh, D. and Biswas, J.K. (2015e). Impact of jute retting on 
phytoplankton diversity and aquatic health: Biomonitoring in a tropical oxbow lake. Journal of Ecological Engineering, 16 (5):15-25, DOI: 10.12911/22998993/60449

Ghosh, D. and Biswas, J.K. (2017a).Erosion of fish diversity: Ranking degree of dangers of unsustainable Fishing gears in a Tropical Oxbow lake in eastern India, International Journal of Chemical and Biological Sciences, 3(12): 1-17.

Ghosh, D. and Biswas, J.K. (2017b). Fish productivity: Assessing sustainability in a tropical oxbow lake of Nadia district, West Bengal, India. Archives of Agriculture and Environmental Science, 2(1): 6-20.

Ghosh, D. and Biswas, J.K. (2017c). Fish Fauna Faces Anthropogenic Double Trouble: Erosion of Fish Diversity in Tropical Oxbow Lake of the Ganga River Basin in Eastern India. Journal of Biodiversity and Endangered Species 5: 188. DOI: 10.4172/2332-2543.1000188

Ghosh, D. and Biswas, J.K. (2017d). Efficiency of Pollution Tolerance Index (PTI) of macroinvertebrates in detecting aquatic pollution in an oxbow lake in India, Universitas Scientiarum, 22(3):237-261.

Golterman, H.L., Clymo, R.S. and Ohnstad, M.A.M. (1978). Methods for physical and chemical and analysis of freshwaters. Oxford, Blackwell, (IBP Handbook), pp. 315

Hart, A.I. and Zabbey, N. (2005). Physico-chemistry and benthic fauna of Woji Creek in the Lower Niger Delta, Nigeria. Environment and Ecology, 23(2): 361-368.

Jhingran, V.G. (2002). Fish and Fisheries of India. Hindustan Publishing Corporation, Delhi:728

Joadder, A.R. (2009). An Ecological Study on the Beel Joshi (Rajshahi District), Northern Bangladesh. Journal of Fisheries International, 4(2): 23-29.

Joo, G.J. and David, F.A. (1995). Limnological Characterization of the Tristate Oxbow Wetland (Ohio, Indiana), The Ohio Journal of Science, 95(5):316-320.

Koliyar, J.H. and Rokhare, N.S. (2008). Water quality in Pawai Lake: Mumbai, Maharashtra. In Sengupta, M. and Dalwani, $\mathrm{R}$ (Editors). Proceedings of Taal, 2007: The $12^{\text {th }}$ World Lake Conference pp.1655-1659

Mbalassa, M., Bagalwa, J.J.M., Nshombo, M. and Kateyo, M.E. (2014). Assessment of physicochemical parameters in relation with fish ecology in Ishasha River and Lake Edward, Albertine Rift Valley, East Africa. International Journal of Current Microbiology and Applied Sciences, 3(6): 230-244.

McNeely, R.N., Neimanis, V.P. and Dwyer, L. (1979). Water quality sourcebook. A guide to water quality parameters. Ottawa: Inland waters directorate, water quality branch.

Moyle, J.B. (1945). Some chemical factors influencing the distribution of aquatic plants in Minnesota. American Midland Naturalist, 34:402-426.

Nandan, S.B. (1997). Retting of coconut husk - a unique case of water pollution on the South West coast of India, International Journal of Environmental Studies, 52:1-4, 335-355, DOI: 10.1080/00207239708711110

Obire, O., Tamuno, D.C. and Wemedo, S.A. (2003). Physicochemi- cal quality of Elechi Creek in Port Harcourt, Nigeria. Journal of Applied Science and Environmental Management ,7: 43-49.

Olive, J.H., Morrison, J.H. and Riley, C.V. (1968). Primary productivity-Phytoplankton relationships, Hodgson lake Portage County, Ohio. The Ohio Journal of Science, 68 (3):152-160.

Patil, S.G. and Panda, P. (1986). Impact of factory effluents on the water quality and biota of Peddacheru. Hydrobiologia, 33:117-143.

Saha, M.N., Saha, A.R. and Mandal, T.C. (1999).Effect of jute retting on environment and its agricultural significance. Environment and Ecology, 17(3): 585-587.

Selvaraj, G.S.D. (2005). Assessment of biochemical oxygen demand (BOD) in tropical aquatic systems (Modified). CMFRI special publication mangrove ecosystems: A manual for the assessment of biodiversity, 83:201.

Sikoki, F.D. and Zabbey, N. (2006). Environmental gradients and benthic community of the middle reaches of Imo River, South -Eastern Nigeria. Environment and Ecology, 24(11): 32-36.

Srinivasan, A. (1967). Primary production and fish yield in a tropical impoundment, Stanley reservoir, Mettur dam, Madras state, South India. Proceedings of the National Academy of Sciences, India Section B: Biological Sciences, 35(2):125-130.

Sugunan, V.V., Vinci, G.K., Bhattacharya, B.K. and Hassan, M.A. (2000). Ecology and fisheries of Beels in West Bengal. Central Inland Fisheries Research Institute Bulletin, 103: 53.

Trisal, C.L. (1985).Trophic status of Kashmir Lakes. In: Misra SD, Sen DN and Ahmad I (eds.) Proc. Nat. Symp. Evalu. Environ. Geobios Supplement, Jodhpur, India: 164-170.

Vass, K.K. and Zutshi, D.P. (1979). Limnological studies on Dal Lake, Kashmir-Morphometry and physical features. Journal of Inland fisheries Society of India, 2(1):12-21.

Vollenweider, R.A. (1974). A Manual on Methods of Measuring Primary Production in Aquatic Environments. IBP Handbook no $12,2^{\text {nd }}$ ed, Blackwell Scientific Publications Oxford, pp. 225.

Water Resources Department (2009). Laboratory testing procedure for soil and water sample analysis, Directorate of irrigation research and development, Pune, India

Wetzel, R.G. and Likens, G.E. (1991). Limnoloical Analyses, Philadelphia, pp.767.

Wetzel, R.G. (1983). Limnology, 2nd ed. Holt, Rinchart and Winston. Philadelphia: Saunders College Publishing. xii $+767+$ R81:120

Ziauddin, G., Chakraborty, S.K., Jaiswar, A.K. and Bhaumik, U. (2013). Seasonal variation of physicochemical parameters of selected floodplain wetlands of West Bengal. Journal of Chemical, Biological and Physical Sciences, 3(4): 27312743.Zutshi, D.P., Kaul, V. and Vass, K.K. (1972). Limnology of high altitude Kashmir lakes. Verhandlungen des Internationalen Verein Limnologie, 18: 599-604.

Zutshi, D.P., Subla, B.A., Khan, M.A. and Wangnoo, A. (1980). Comparative limnology of nine lakes of Jammu and Kashmir Himalayas, Hydrobiologia, 72: 101-112. 